\title{
PENINGKATAN KAPASITAS PENGELOLAAN DESA WISATA KAFE SAWAH PUJON KIDUL
}

\author{
Erlin Melani' ${ }^{1)}$, Aang Afandi $^{2)}$, Andi Kusuma Indrawan ${ }^{3)}$ \\ 1, 2,3 Jurusan Akuntansi Politeknik Negeri Malang \\ erlinmleani13@gmail.com
}

\begin{abstract}
Abstrak
Wilayah Kabupaten Malang menyimpan banyak potensi wisata yang cukup memiliki prospek untuk dikembangkan. Salah satunya yaitu desa wisata Pujon Kidul yang terletak di kecamatan Pujon. Desa wisata ini dikemas dalam bentuk kafe yang menyajikan aneka jenis makanan dan menawarkan nilai lebih yaitu sensasi makan di tengah sawah. SDM yang dimiliki oleh Kafe Sawah memiliki keterbatasan dalam hal latar belakang pendidikan. Awalnya mereka sebagian besar berprofesi sebagai petani. Untuk meningkatkan kapasitas desa wisata dan kafe sawah pada khususnya, maka diperlukan beberapa pelatihan dan pendampingan. Pelatihan dan pendampingan yang dilakukan yaitu pelatihan bahasa inggris. Diharapkan dengan pelatihan yang komprehensif dapat meningkatkan kualitas SDM dan pada akhirnya meningkatkan kapasitas Kafe sawah sebagai destinasi wisata.
\end{abstract}

Keywords: wisata, pelatihan, kapasitas

\begin{abstract}
Malang Regency has a lot of tourism potential spot that has prospects to be developed. One of them is the tourist village of Pujon Kidul, located in Pujon sub-district. This tourist village is packaged in the form of a cafe that serves various types of food and offers more value, namely the sensation of eating in the middle of rice fields. One of the problem faced by Kafe Sawah is the limitation of human resources in terms of educational background. Initially they mostly worked as farmers. To increase the capacity of tourism villages and Kafe Sawah in particular, some training and assistance is needed. Training and mentoring offered include English practice. It is expected that comprehensive training can improve the quality of human resources and ultimately increase the capacity of Kafe Sawah as a tourist destination.
\end{abstract}

Keywords: tourism, training, capacity

\section{PENDAHULUAN}

Wilayah Kabupaten Malang menyimpan banyak potensi wisata yang cukup memiliki prospek untuk dikembangkan. Salah satunya yaitu desa wisata Pujon Kidul yang terletak di kecamatan Pujon. Desa wisata ini dikemas dalam bentuk kafe yang menyajikan aneka jenis makanan dan menawarkan nilai lebih yaitu sensasi makan di tengah sawah. Pengunjung dapat menikmati makanan yang disajikan sambil menikmati pemandangan sawah yang berlatar belakang gunung. Pemandangan yang menyejukkan mata ini menjadi daya tarik tersendiri bagi wisatawan, ditambah lagi dengan udara yang sejuk di daerah pegunungan. Meskipun tergolong baru, kafe sawah memiliki potensi untuk dikembangkan. Selain itu, Kafe Sawah juga dapat menjadi inspirasi bagi daerah lain. 
Konsep desa wisata merupakan wujud dari community based tourism (CBT). Konsep yang digunakan dalam CBT sangat erat kaitannya dengan pemberdayaan, dimana masyarakat diberdayakan terlebih dahulu agar mampu mengembangkan potensinya sendiri, dengan pemberdayaan masyarakat dilatih untuk bisa menolong dirinya sendiri (self help), sehingga, pada pembangunan desa wisata, masyarakat dikembangkan dan diberdayakan untuk mampu mengelola desa wisatanya sendiri.

CBT merupakan bentuk pariwisata yang memberikan kesempatan kepada masyarakat lokal untuk mengontrol dan terlibat dalam manajemen dan pembangunan pariwisata, dimana masyarakat yang tidak terlibat langsung dalam usaha-usaha pariwisata juga mendapat keuntungan, serta menuntut pemberdayaan secara politis dan demokratisasi dan distribusi keuntungan kepada komunitas yang kurang beruntung di pedesaan (Garrod 2001:4).

Hasil survey dan observasi awal yang dilakukan peneliti diperoleh informasi bahwa pihak manajemen Kafe Sawah ingin mengembangkan lagi potensi wisata yang saat ini sudah ada, misalnya dengan mengembangkan konsep homestay. Mereka juga memiliki target untuk menarik minat wisatawan asing. Namun dengan latar belakang pendidikan SDM yang dimilikinya -rata-rata lulusan SD, SMP, SMA- mereka merasa belum memiliki cukup kemampuan untuk berkomunikasi dengan bahasa Inggris.

\section{METODE PELAKSANAAN}

Kegiatan diawali dengan melakukan survey pendahuluan yang dilakukan oleh tim pelaksana PkM pada bulan Juli 2018. Kegiatan ini sekaligus dilakukan bersamaan dengan focus group discussion (FGD) antara tim pelaksana dan manajemen Kafe Sawah. Tujuan dari survey dan FGD adalah untuk mendapatkan gambaran dan informasi yang lengkap berkaitan dengan kebutuhan atau permsalahan yang dihadapi manajemen Kafe selama ini. FGD dilakukan antara tim pelaksana dan manajer SDM yaitu Pak Badur, beberapa karyawan lapangan, dan penanggung jawab laporan keuangan yaitu Bu Tutut.

Permasalahan yang diidentifikasi dari hasil FGD adalah masalah penguasaan bahasa inggris oleh karyawan terutama yang bertugas sebagai guide. Selama ini, ketika ada wisatawan mancanegara (wisman) yang datang tidak ada yang mendampingi karena keterbatasan kemampuan karyawannya dalam berbahasa inggris.

Kegiatan pelatihan ini berlangsung selama 3 bulan, dengan intensitas pertemuan 2 kali seminggu. Setiap pertemuan berlangsung kurang lebih 1 jam. Peserta dibekali tidak hanya teori grammar sederhana, namun juga langsung melakukan praktik percakapan dalam bahasa inggris. Peserta juga dibekali modul yang dirancang oleh tim, materi modul tersebut berkaitan dengan English for guiding.

\section{HASIL DAN PEMBAHASAN}

Kegiatan pelatihan ini bertujuan untuk memberikan pengetahuan- pengetahuan dasar tentang dunia guiding khususnya untuk wisatawan asing dalam berbagai situasi dan kondisi. Capaian utama dari kegiatan ini adalah menumbuhkan keberanian dari setiap guider untuk dapat berkomunikasi dua arah dengan wisatawan asing dengan menggunakan Bahasa Inggris sederhana. Kegiatan ini dilakukan oleh dua orang tutor yaitu mahasiswa D3 Jurusan Akuntansi Politeknik Negeri Malang.

Kegiatan yang dilakukan oleh tim ini yaitu: 


\section{Melakukan initial observation}

Kegiatan ini dilakukan dengan tujuan untuk mengetahui bagaimana kondisi umum di Cafe Sawah serta materi apa saja yang dibutuhkan dalam setiap materi pembelajaran yang diberikan.

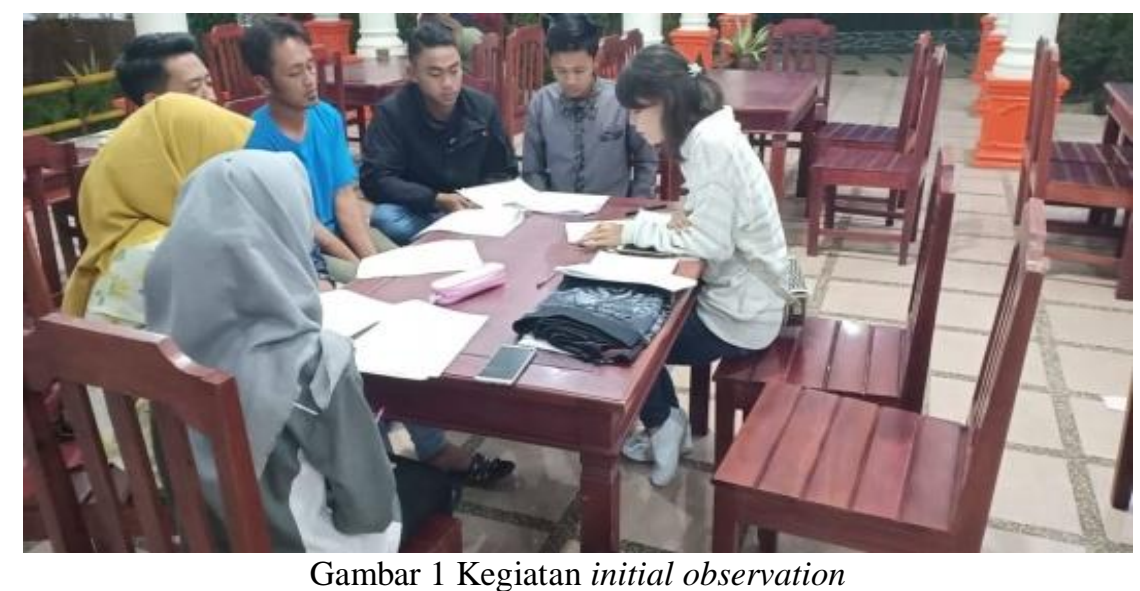

2. Merancang konsep modul

Hal ini dilakukan dengan tujuan agar modul yang dibuat sesuai dengan kebutuhan dan kemampuan setiap peserta atau guider yang ada di Cafe Sawah. Modul yang dibuat akan dibagi ke dalam beberapa bab dan setiap bab akan memiliki topik khusus sesuai dengan permintaan peserta pembelajaran. Setiap bab akan dibagi ke dalam dua bagian utama yaitu teori dan praktik sehingga peserta juga bisa mulai untuk berbicara sedikit demi sedikit di tiap pertemuan.

3. Pembagian tugas

Sebelum memulai pembelajaran, terdapat waktu khusus untuk berlatih dalam menyampaikan materi atau biasa disebut dengan team split sehingga ketika pembelajaran, penyampaian materi dapat terlihat lebih apik dan sistematis.

4. Pelaksanaan Kegiatan

Pelatihan diawali dengan Perkenalan diri antara trainer dan karyawan Kafe Sawah yang terdiri dari dua macam kelompok karyawan, yaitu karyawan Live in (karyawan yang bertugas sebagai pemandu di institusi pemerintah, baik di tingkat desa maupun kabupaten) dan karyawan kafe (karyawan yang bekerja di kafe). Dari hasil pertemuan tersebut diperoleh informasi mengenai item atau pertanyaan yang biasa ditanyakan oleh turis asing kepada karyawan sebagai salah satu bahan untuk pembuatan modul. Karyawan juga memberikan data kepada trainer berupa dokumen tentang kafe sawah, meliputi sejarah kafe sawah, menu kafe, sarana dan prasarana yang ada di kafe sawah. Tim juga melakukan Observasi sarana dan prasarana yang ada di cafe sawah meliputi wahana permainan, berbagai komoditi yang ditanam, fasilitas umum beserta penjelasan dari masing-masing objek. 


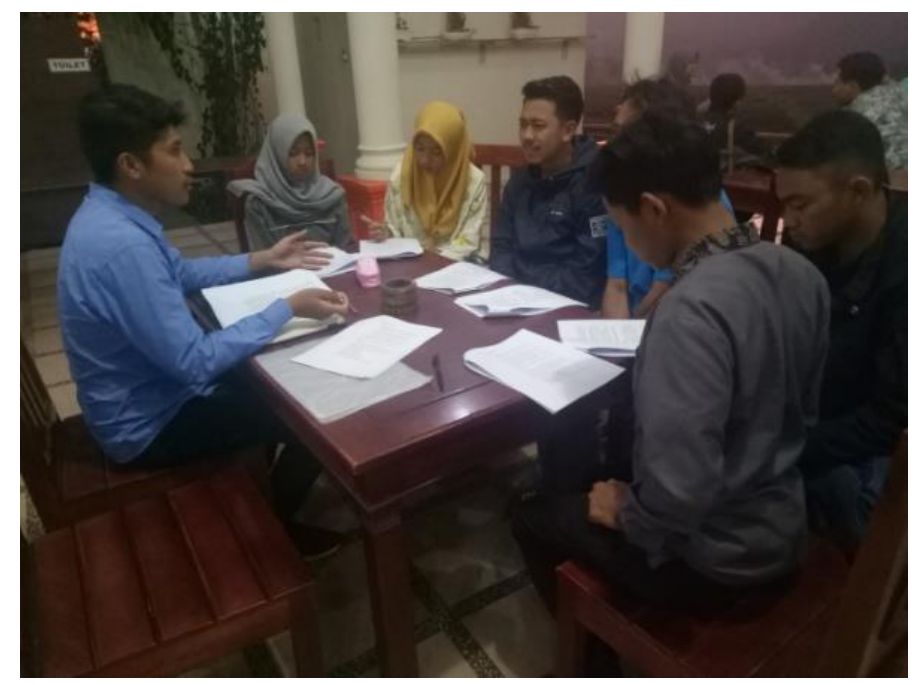

Gambar 2. Pelaksanaan Pelatihan 1

Pertemuan selanjutnya langsung masuk ke pemberian materi yaitu:.

1. Dasar-dasar Guiding

Diharapkan setelah pealtihan ini karyawan Cafe Sawah dapat mengetahui dasardasar dari Guiding yang meliputi bagaimana menjadi Guider yang baik serta apa yang harus sebaiknya dilakukan dan tidak dilakukan oleh seorang guider.

2. Pengenalan vocabulary

Karyawan Cafe Sawah dikenalkan dengan beberapa vocabulary terkait dengan wisata, khususnya Kafe Sawah sehingga mereka dapat menjelaskan gambaran umum mengenai Café Sawah kepada turis asing dalam bahasa inggris.

\section{Grammar}

Materi ini memperkenalkan cara membuat kalimat sederhana, diharapkan karyawan Kafe Sawah dapat mengetahui dan mengaplikasikan pertanyaan yang biasa ditanyakan oleh turis asing serta menjelaskan sebuah barang dan menu kafe dalam bahasa inggris kepada turis asing

4. Pengenalan mata uang asing

Materi ini bertujuan agar karyawan Kafe Sawah dapat mengetahui dan mengaplikasikan penggunaan mata uang, khususnya dalam melakukan pembayaran bill oleh turis asing serta dapat mengonversikan mata uang asing, khususnya dolar, ke mata uang rupiah.

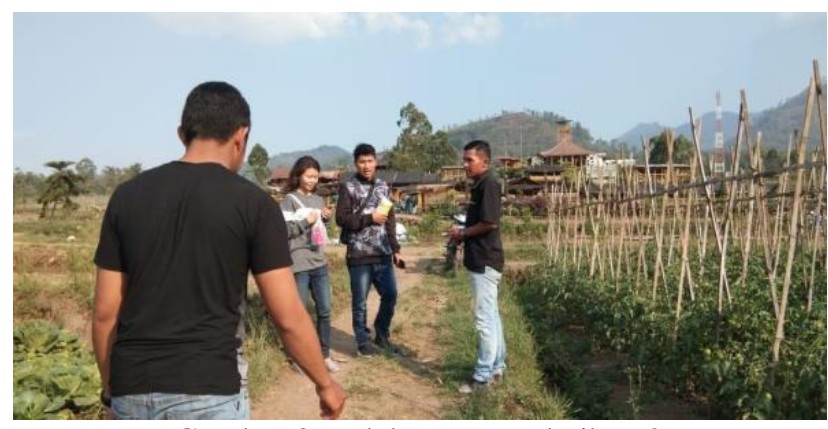

Gambar 3. Pelaksanaan Pelatihan 2 
Beberapa kendala yang terjadi saat pelatihan yaitu:

1. Peserta terkadang kurang tertarik dengan dasar teori yang diberikan sehingga tutor harus menemukan cara yang lebih sederhana namun tetap interaktif dalam menjelaskan materi tersebut.

2. Peserta terkadang lebih tetap memilih untuk menggunakan Bahasa Inggris ala kadarnya dikarenakan mereka terbiasa untuk menggunakan cara yang praktis dalam menyampaikan informasi ataupun memberi penjelasan kepada wisatawan asing. Namun demikian, patut diapresiasi bahwa seluruh peserta cukup mudah untuk diajak berkomunikasi bahasa Inggris.

Namun, meskipun terdapat beberapa kendala, keinginan dari tiap peserta untuk memahami cara memandu dalam Bahasa Inggris cukup tinggi karena mereka berinisiatif untuk mengajukan materi-materi yang menurut mereka sangat dibutuhkan dalam melaksanakan kegiatan sehari-harinya.

\section{SIMPULAN}

Pelatihan bahasa inggris yang telah dilakukan dapat meningkatkan kapabilitas karyawan Kafe Sawah. Setidaknya mereka lebih percaya diri ketika menyambut tamu wisatawan mancanegara. Penguasaan bahasa dapat memperlancar komunikasi yang pada akhirnya bisa menambah kepuasan wisatawan.

\section{DAFTAR PUSTAKA}

Garrod, B. (2001). Local Participation in The Planning and Management of EcoTourism. A revised Model Approach. Bristol England: University of the West England. 